\title{
Struktura działań komunikacyjnych w koncepcji pragmatyki formalnej J. Habermasa
}

\author{
Stawomir Sikora \\ Institute of Linguistics, Adam Mickiewicz University \\ ul. Międzychodzka 5, 60-371 Poznań, POLAND
}

\begin{abstract}
This paper gives an analysis of some basic concepts and categories in formal pragmatic of J. Habermas. His theory allows to parameterise the pragmatic analyses and base them on the assumption of the speaker's rationalism which refers in turn to the question of the truth of utterances, their sincerity and the legitimacy of norms and regulations accepted by language users in inter-subjectively divided worlds.
\end{abstract}

\section{Wstęp}

Ostatnie dwadzieścia lat minionego wieku obfitowało wzmożonym wzrostem zainteresowań problematyką pragmatyki językowej. W większości zaistniałych koncepcji dominowało nomotetyczno-przyczynowe podejście do wyjaśniania zjawisk językowych. W językoznawstwie zaowocowało to pojawieniem się teorii analizy tekstów, w socjolingwistyce powstały próby analizy konwersacji, zaś badania nad pragmatycznymi warunkami interakcji językowych zdominowały psycholingwistykę.

Ze zgoła innym podejściem mamy do czynienia w przypadku pragmatyki formalnej J. Habermasa. Szeroko i wnikliwie omawiana w Teorii działań komunikacyjnych ${ }^{1}$ koncepcja pragmatyki komunikacyjnej budowana jest raczej w duchu teorii kompetencji, z nadzieją autora na rekonstrukcję zapośredniczonych językowo czystych typów (w sensie M. Webera) i interakcji społecznych.

Treścią tego artykułu nie jest rekonstrukcja czy też interpretacja teorii działań komunikacyjnych, lecz jedynie zarysowanie jej wąskiego fragmentu, który kieruje nas w stronę działań językowych. Postaramy się również wskazać na ograniczenia i trudności bez rozwiązania których, teorii J. Habermasa trudno będzie podjąć wyzwanie kompleksowej analizy działań komunikacyjnych.

Problematyka działań ludzkich przenika filozoficzną myśl europejską od Platona po czasy współczesne. Jednak pierwsze systematyczne próby określania specyfiki działań poznawczych, warunków ich zachodzenia, przebiegu czy prawomocności odnajdujemy w modernistycznej myśli I. Kanta. Ona to stała się inspiracją dla W. Jamesa, Ch. Peirce'a, W. Diltheya, M. Webera, A. Schutza, S. Parsonsa i wielu innych, dla których rozważania wokół ludzkich działań stały się centralną problematyką filozofii. Na nowo odkryte i zdefiniowane pojęcie działania, dla wielu filozofów XX wieku jest kluczem do zrozumienia i wyjaśniania sensu człowieczeństwa w ogóle. Formułowana $\mathrm{z}$ tej płaszczyzny problematyka pozwoliła dostrzec, że dzięki analizie działań ludzkich możemy pozyskać nowe punkty zaczepienia dla rozważań etycznych, antropologicznych,

${ }^{1}$ Habermas, J. 1999. Teoria działania komunikacyjnego. Warszawa: Wydawnictwo Naukowe PWN. 
epistemologicznych jak również lingwistycznych. W konsekwencji na nowo została podjęta kwestia racjonalności jednostki ludzkiej, wolnej woli człowieka, czy roli jaką odgrywają wartości i reguły w działaniach społecznych.

Zasoby wiedzy odnoszącej się do tej problematyki, ujęte w sposób systematyczny w postaci teorii, próbują w największej ogólności dokonać próby wyjaśnienia i zdefiniowania pojęcia działania i pojęć jemu pokrewnych. Prowadzą analizę struktur wewnętrznych działań, formułując zasady ich racjonalności oraz sposoby funkcjonowania działań w społeczeństwie. Teorie takie dają początek interpretacji konkretnych zachowań ludzkich, w tym działań językowych, które jak wiemy - stanowią przedmiot zainteresowań szeroko rozumianych badań lingwistycznych ${ }^{1}$. W ten nurt doskonale wydaje wpisywać się teoria działań komunikacyjnych J. Habermasa.

\section{Epistemiczne działania językowe}

Zacznijmy od pewnej uwagi, która odnosi się do ożywionych ostatnio sporów wśród filozofów i lingwistów, a dotyczącej tzw. dualizmu schematu i treści. Idzie tutaj o spór wokół wzajemnych reakcji między językiem, a strukturą jego odniesień przedmiotowych; czy pojęcia języka odgrywaja jakaśs rolę, a jeżeli tak, to jaka, w kreacji schematów systematycznie porządkujących świat i organizujących treści empiryczne (problem tzw. ontologicznego umeblowania świata).

Historycznie sprawcą tego niepokoju wydaje się być wyrażona przez Kanta opinia, że: [...] Nie możemy sobie pomyśleć żadnego przedmiotu inaczej, jak tylko przez kategorie. Żadnego pomyślanego przedmiotu nie możemy inaczej poznać, jak przez dane empiryczne, które owym pojęciom odpowiadają ${ }^{2}$.

Obecność intuicji wyrażonych w tym zdaniu dostrzegamy w większości znaczących teorii semantycznych XX wieku. Obserwujemy jej znaczący wpływ na koncepcję sensu i znaczenia G. Fregego, konstytuuje ona filozoficznie Russellowską teorię atomizmu logicznego i teorię obrazkową L. Wittgensteina. Obecna jest współcześnie w behawioralnej teorii znaczenia Quine’a ${ }^{4}$, czy też w tezach realizmu wewnętrznego H. Putnama ${ }^{5}$. Wyjątkiem są tutaj koncepcje tzw. „nieobecności znaczenia” reprezentowane w dekonstruktywistycznych nurtach współczesnej filozofii języka.

W filozofii przetransformowanej J. Habermasa, dokonuje się przeniesienia punkt ciężkości w filozofii języka z prymarnych pojęć semantycznych: nazwy i zdania, na pojęcia pragmatyczne: dyskursu i porozumienia się. Jest to konsekwencją przyjęcia za pierwotną funkcję języka funkcję otwierania świata.

,[...] Racjonalne zachowanie umożliwia język wraz z kategoryzacją i gramatycznie pierwotna strukturalizacją rozumienia tła świata życia (Lebenswelt). Komunikacyjnie działające jednostki porozumiewają ze soba, co do czegoś (Verstandingung) w obiektywnym świecie, poruszają się w obszarze swojego świata życia. Im bardziej poza niego wykraczaja, tym bardziej linia horyzontu świata życia przesuwa się, tak że nigdy nie mogą go ogarną́ wzrokiem”. komunikacyjne nie są niczym innym, jak tylko systemem społecznie warunkowanych powiązań życiowych, które łączą się wzajemnie w społecznej przestrzeni i historycznie odniesionym czasie.

To pewne typy mocy illokucyjnych wykształcone i historycznie przekazywane w różnych językach odwzorowują strukturę takich powiązań. Język za pośrednictwem trybów gramatycznych, formie czasowników kauzatywnych, różnego rodzaju partykuł zdaniowych czy też intonacji zdań, dostarcza schematów dla tworzenia zachowań interpersonalnych. Punktami węzłowymi w strukturach komunikacyjnej socjalizacji jednostek są illokucyjne moce działań językowych.

\footnotetext{
${ }^{1}$ Zob. np. Buksiński, T. 1991. Szkice z filozofii działań. Poznań: Wydawnictwo Naukowe Instytutu Filozofii UAM w Poznaniu.

${ }^{2}$ Kant, I. 1957. Krytyka czystego rozumu. Warszawa: Wydawnictwo Naukowe PWN, s. 165.

${ }^{4}$ Por. Quine, W.V. 1960. Word and Object. Massachusetts: Massachusetts Institute of Technology Press.

${ }^{5}$ Por. H. Putnam, Wiele twarzy realizmu. [W:] H. Putnam (red.) 1998. Wiele twarzy realizmu i inne eseje, Warszawa: Wydawnictwo Naukowe PWN, ss. 325-431.

${ }^{6}$ Habermas, J. 1997. Pojęcie racjonalności komunikacyjnej w świetle teorii aktów mowy. [W:] T. Buksiński (red.) Rozum i racjonalność. Poznań: Wydawnictwo Naukowe Instytutu Filozofii UAM w Poznaniu, s. 73.
} 
Płaszczyzną na której przecinają się wzajemnie język i instytucjonalne porządki społeczne jest zbiór mocy illokucyjnych funkcjonujących w danej społeczności.

Analizę działań, które nazywać się będzie epistemicznymi działaniami językowymi, J. Hebermas rozpoczyna od wyjaśnienia użycia słowa wiedza ${ }^{7}$. Do etymologii słowa wiedza należy wszystko co składa się na zasób naszych informacji i przekonań, oraz wszystko to, co po pierwsze wymaga uzasadnienia, a po drugie podlega krytyce ${ }^{8}$.

Posiadamy rzeczywistą wiedzę o kimś lub o czymś dopiero wtedy, gdy sądy formułowane o kimś lub o czymś są sądami prawdziwymi, a ponadto, gdy wiemy dlaczego prawdziwymi są właśnie. Podstawowa bierna znajomość faktów o rzeczach lub osobach nie upoważnia nas do formułowania wypowiedzi o postaci: stwierdzam, że coś wiem o... Tego rodzaju wiedza starcza jedynie do tego, by powiedzieć jak coś się robi, jak coś się dzieje. Czysta znajomość faktów jest wiedza jak i ma charakter wiedzy praktycznej o tym jak coś wykonać, a nie jakie coś jest. Często w codziennym życiu spotykamy ludzi, którzy bardzo dobrze znają się na czymś, ale nie wiedzą czym to coś w istocie jest, co stanowi o kompetencji naszego znawstwa rzeczy. Wiedza tego rodzaju ma charakter intuicyjny i nazywana jest wiedzq implicite.

Zatem jest tak, że jeżeli podejmuję się orzekać, że coś wiem na pewien temat to tym samym przyjmuję na siebie obowiązek przedstawienia argumentacji na rzecz wyjaśnienia roszczeń wnoszonych wobec tej wiedzy. Wiedza tego rodzaju, za którą stoi możliwość argumentacji na rzecz jej uzasadnienia jest wiedzą dlaczego, a o podmiocie posiadającym taką wiedzę, mówimy że posiada wiedzę explicite ${ }^{9}$.

Osobę, która potrafi argumentować na rzecz prawomocności wypowiadanych przez siebie sądów, Habermas nazywa osobą racjonalną.

Jak doskonale nam wiadomo, zarówno wiedza jak oraz wiedza dlaczego pojawiająca się w wypowiedziach językowych, formułowana jest w postaci sensownych jednostek języka (proposition), które mogą być prawdziwe lub fałszywe. Intrygującym wydaje się być postawienie w tym miejscu pytania: jak się ma fałszywość wypowiadanych przez osobę sądów do jej racjonalności? Czy wypowiadając sądy fałszywe jestem tym samym osobą nieracjonalną? Za sprawą sarkastycznych rozważań L. Wittgensteina ${ }^{10}$, wiemy bowiem, że nie rzecz $\mathrm{w}$ tym, by formułować wyłącznie sądy prawdziwe, rzecz w tym, by formułować sądy sensowne i posiadać metodę weryfikacji ich sensowności. Habermasa kategoria racjonalność skorelowana jest z sensownością wypowiedzi językowych, a nie z ich prawdziwością lub fałszywością. Nie jest nieracjonalny ktoś głoszący poglądy nieprawdziwe, lecz ten, kto upiera się przy nich dogmatycznie, nie potrafiąc jednocześnie ich uzasadnić, czy na ich rzecz argumentować.

Kolejny problem stanie przed nami, gdy odwrócimy postawione wcześniej pytanie i zapytamy: czy jesteśmy racjonalni zawsze i tylko, gdy wypowiadamy sądy prawdziwe (prawomocne)? Jeżeli pójdziemy jeszcze dalej i zrelatywizujemy pojęcie prawdy, to innej odpowiedzi na to pytanie możemy oczekiwać od zwolennika tzw. dyskwotacyjnego ujęcia prawdy, np. Quine, a innej od zwolenników jej klasycznego przedstawienia, np. Tarski ${ }^{11}$. Czy zatem, racjonalność odniesiona

\footnotetext{
7 W swoich rozważaniach J. Habermas nie rozróżnia poszczególnych rodzajów działań językowych, rozróżnia natomiast rodzaje racjonalności poszczególne działania językowe warunkujące.

${ }^{8}$ Poglądy J. Habermasa dotyczące natury i rodzaje wiedzy podmiotowej, wydają się być zbieżne z tymi, które po raz pierwszy zaistniały w filozofii języka XX w., za sprawą eseju B. Russella z 1918 roku: Knowledge by Acquaintance and Knowledge by Descriptio. [W:] Mysticism and Logic. London: Longmans, Gree and Co.

${ }^{9}$ Habermas, J. Pojęcie racjonalności..., s. 55.

${ }^{10}$ Wittgenstein, L. 1970. Tractatus logico-philosophicus, Warszawa: Wydawnictwo Naukowe PWN, tezy: 4.003-7.

${ }^{11}$ Przedstawiciele neopragmatyzmu we współczesnej filozofii języka twierdza, że A. Tarski w: Pojęcie prawdy w jezzykach nauk dedukcyjnych mylił się co do tego, że konwencja $\mathrm{T}$ wyraża w sposób formalny intuicyjną prawdziwość w sensie klasycznym. Pojęcie „,prawdy” rozumieją oni jedynie jako metajęzykowe narzędzie opisue języka, które oznacza asercję określonego stwierdzenia przedmiotowego. Stąd też tego rodzaju rozumienie ,prawdy” nazywa się dyskwotacyjnym, czyli usuwającym nawias. Egzemplifikację tego stanowiska stanowi esej D. Davidsona o przewrotnym tytule: W obronie Konwencji T. Davidson, D. 1992. Eseje o prawdzie języka i umyśle, Warszawa: Wydawnictwo Naukowe PWN, ss. 76-95.
} 
do prawdziwości dyskwotacyjnej różnić by się miała od racjonalności odniesionej do prawdziwości w jej klasycznym ujęciu?

Racjonalność odnoszona do zasobów wiedzy osoby wypowiadającej dane sądy sensowne (określanej mianem wiedzy epistemicznej) zakładana jest zarówno w koncepcji Quine'a jak i A. Tarskiego, bowiem istota racjonalności zawiera się w mocy uzasadniającej na rzecz działań językowych wnoszonych przez samo np. stwierdzanie faktów, stawiania hipotez, etc., a nie w prawdziwości samych wypowiedzi (poziom semantyczny). Na mówiącym spoczywa obowiązek argumentacji na rzecz tego, dlaczego np. należy twierdzić, że..., a nie tylko przypuszczać, że... Stąd też możemy mówić o pewnej uniwersalności kategorii racjonalności epistemicznej w stosunku do pojęcia prawdy.

Zauważmy, że uniwersalizm racjonalności epistemicznej wyrażany w konieczności argumentacji na rzecz ważności wnoszonych działań językowych poprzedza, a jednocześnie warunkuje każdy z postmodernistycznych dyskursów, podważając tym samym ich deklaratywny relatywizm i dekonstrukcjonizm.

Racjonalność epistemiczna odnosząca się do działania wnoszonego przez wypowiedź językową jest możliwa dlatego, że mamy możliwość prezentacji naszej wiedzy w zdaniach, jak również możemy ją poprawiać i poszerzać tzn. uczyć się z błędów. Na tej płaszczyźnie krzyżuje się racjonalność epistemiczna z używaniem języka i działaniem ${ }^{12}$.

Tylko językowa prezentacja tego co wiemy oraz możliwość konfrontacji tej wiedzy z rzeczywistościa, w trakcie której oczekiwany przez nas skutek może wystapić lub nie, daje nam możliwość racjonalnego obchodzenia się z wiedza.

Dokonajmy krótkiego podsumowania: z całego szeregu możliwych działań ludzkich (czynności konstruowanych na projektach) wyodrębnić można te, które realizowane są w ramach wspólnego medium językowego. Działania takie, w których działający podmiot dokonuje prezentacji swojej wiedzy $\mathrm{w}$ oparciu o epistemiczną strukturę zdań nazywać będziemy językowym działaniem epistemicznym.

Racjonalność takiego działania nie odnosi się do prawdziwości lub fałszywości prezentowanych przez podmiot działający poglądów, lecz odnosi się do działania wnoszonego przez wypowiedzi językowe dane poglądy prezentujące. Działanie podmiotu jest w tym przypadku racjonalne, kiedy podmiot potrafi argumentować na rzecz zasadności wygłaszanych przez siebie poglądów, a racjonalność tego rodzaju określa się racjonalnościq epistemicznq.

\section{Językowe działanie teleologiczne}

Z szeroko znanych analiz ludzkich działań prowadzonych między innymi przez A. Schutza $\mathrm{w}$ The Phenomenology of the social World ${ }^{13}$ wynika, że działamy zarówno wtedy, gdy przekształcamy materialną rzeczywistość, jak również, gdy wchodzimy w interakcje społeczne. Działamy komunikując coś współużytkownikom świata społecznego. Postępowanie nasze raz odbywa się tylko według obowiązujących schematów (reguł), innym zaś razem podejmowane przedsięwzięcia dajemy pod staranną rozwagę, wybierając najlepszą drogę do osiagnięcia zaplanowanego celu. Ukierunkowując siebie w działaniu na przyszłość, zadajemy ciagle pytanie, czy postapiliśmy rozważnie, czy też nie. Z błędów próbujemy wyciagać pozytywne wnioski. Działanie - zgodnie z proponowaną przez A. Schutza definicją - to celowe zachowanie ludzkie, budowane na poprzedzającym je projekcie ${ }^{14}$. Jest ono zatem niczym innym, jak tylko naszym codziennym postępowaniem w świecie; ale tylko takim postępowaniem, które jest wcześniej planowane. Jeżeli działający podmiot nie ma projektu działania to mówimy o nim, że jedynie zachowuje się lub doświadcza. Proces planowania czynności odniesiony jest zawsze do świadomości podmiotu działającego. Podkreślmy wobec tego wypływające z powyższego stwierdzenie, że tym, co konstytuuje działanie per se jest świadomość działającego podmiotu.

\footnotetext{
${ }^{12}$ Habermas, J. Pojęcie racjonalności..., s. 56.

${ }^{13}$ Schutz, A. 1972. The Phenomenology of the social World. London.

14 Tamże, s. 239.
} 
Zasób doświadczeń pozwala mu na czerpanie wiedzy niezbędnej do konstrukcji projektu działania, a dalej umożliwia mu wybór procedur i środków dla osiagnięcia wyznaczonego celu.

Jak mieliśmy już sposobność stwierdzić to wyżej, każde z ludzkich przedsięwzięć - nazywane za Schutzem działaniem - ma charakter intencjonalny. W szczególności każde językowe działanie ma również charakter intencjonalny. Jednak w wielu działaniach językowych, działające podmioty, jako cel główny swojej wypowiedzi, stawiają nie jak było to $\mathrm{w}$ językowych działaniach epistemicznych, zajęcie pewnej postawy asercyjnej do zachodzenia, bądź nie, faktów w świecie, lecz idzie im o osiagnnięcie planowanego skutku jako konsekwencji formułowanej przezeń wypowiedzi. Ponieważ każdy zamiar tego typu działania skierowany jest na osiagnięcie planowanego skutku, zatem o takich działaniach językowych powiemy, że mają strukturę teleologiczna. Za Wrightem, Habermas sugeruje, iż to co miałoby uzasadniać i jednocześnie motywować podmioty do tego typu działań językowych, przyjmuje formułę praktycznej reguły: przy danych preferencjach podmiot działający A zamierza w sytuacji $\mathrm{S}$ spowodować stan (sytuację) p. W danych warunkach $\mathrm{K}$ podmiot A uważa, że użycie środków $\mathrm{M}$ jako warunku koniecznego, bądź jako warunku wystarczającego z pewnym prawdopodobieństwem spowoduje stan (sytuację) $\mathrm{p}^{15}$. Strukturę takiego typu działania językowego określa się jako strukturę teleologicznq, samo działanie zaś językowym działaniem teleologicznym.

Analogicznie, jak miało to miejsce w stosunku do struktury epistemicznej, również działanie językowe konstruowane w oparciu o strukturę teleologiczną może być parametryzowane przez pojęcie racjonalności. Racjonalność działania językowego o strukturze teleologicznej parametryzować należy w odniesieniu do tego, czy sytuacja będąca skutkiem określonego działania osiagnnięta została na podstawie planowo wybranych i właściwie użytych środków osiagania skutku. Działanie językowe teleologiczne jest racjonalne wtedy, gdy:

- działający podmiot wie dlaczego osiagnął dany skutek lub mógłby go osiagnąć przy normalnych tzn. niezakłóconych warunkach K;

- wiedza podmiotu wyrażona $\mathrm{w}$ wypowiedzi o strukturze epistemicznej zawiera informacje mogące być wyjaśnieniem osiąniętego skutku.

Zwrócimy uwagę na fakt, że praktyczna refleksja za pomocą której podmiot dokonuje budowy planu działania ma swoje źródło w zasobie informacji o świecie, które o nim żywi. Informacje te są w drugiej fazie - co zresztą oczywiste - przetwarzane językowo. To właśnie w ten sposób, zarówno proste zamiary działań językowych jak i kompleksowe problemy związane z decyzjami działających podmiotów są ustrukturyzowane językowo. Tak jak wiedza propozycjonalna wymagała stosowania zdań orzekających do językowego wyrażenia, tak działania teleologiczne do własnej realizacji wymagają zdań deklaratywnych, np.: obiecuje, że..., przyrzekam, że...

\section{Językowe działania komunikacyjne}

Kolejnym, trzecim a jednocześnie i ostatnim $\mathrm{z}$ wyróżnionych działań językowych $\mathrm{w}$ teorii J. Habermasa są językowe działania komunikacyjne. Treści, które mówiący pragnie przekazać w działaniu komunikacyjnym nierozerwalnie łączą się zarówno z tym co podmiot mówi dosłownie, jak również z samym działaniem, ponieważ to co powiedziane, każdorazowo powinno być odebrane jako konkretne działanie samo w sobie. Rozumiemy znaczenie działań językowych wtedy, gdy wiemy, ze względu na jakie warunki są one uznawane za ważne w procesie komunikacji. Znaczenie wyrażeń języka musi wobec tego implikować trojakiego rodzaju relacje semantyczno-pragmatyczne:

- relacje zachodzące między znaczeniem wyrażeń języka, a tym co chciało się powiedzieć;

- relacje zachodzące między znaczeniem wyrażeń języka, a tym co zostało powiedziane;

- relacje między wyrażeniem języka, a rodzajem jego użycia w działaniu językowym.

Pierwsza z relacji wyznacza nam fazę projektu działania językowego, druga określa sposób jego realizacji, w trzeciej natomiast dokonuje się wybór odpowiednich środków językowych. Parafrazując grande estime filozofii języka XX wieku L. Wittgensteina, możemy powiedzieć,

\footnotetext{
${ }^{15}$ Zob. Von Wright, G.H. 1991. Explanation and Understanding. London: Routledge and Kegan Paul, ss. $83-132$.
} 
że nie zawsze cokolwiek da się w ogóle pomyśleć, da się jasno pomyśleć, oraz nie zawsze cokolwiek da się wypowiedzieć, da się jasno wypowiedzieć ${ }^{16}$. Do swobodnie działającego podmiotu należy przecież wybór zakresu spełnialności tych trzech relacji w działaniu językowym. Jednak to co leży poza podmiotem, to co względem niego transcendentne, to nadrzędny cel każdego działania komunikacyjnego, cel porozumienia się z kimś, co do czegoś. W działaniu komunikacyjnym mówiący wybiera zrozumiałe dla słuchającego wyrażenia językowe, nie tylko po to, by porozumieć się ze słuchającym co do czegoś, ale również by samego siebie uczynić zrozumiałym. Do komunikacyjnej intencji należy wobec tego (1) wykonanie właściwej ze względu na kontekst normatywny czynności językowej po to, by między mówiącym a słuchającym doszło do zachowania uznanego za uprawnione (legitim); (2) wypowiedzenie prawdziwego sądu (Aussage), ażeby mówiący i słuchający podzielił i ewentualnie przyjął wiedzę mówiącego; (3) szczere wyrażenie zamiarów i uczuć, po to by słuchający dał wiarę temu co po prostu powiedziane. Zgodzenie się ze sobą co do czegoś, na odpowiedniej płaszczyźnie normatywnej, podzielanie wiedzy propozycjonalnej oraz wzajemne zaufanie co do szczerości podejmowanych działań językowych daje się wyjaśnić tylko w oparciu o odwołanie się do podstawowej i intersubiektywnej funkcji języka - porozumienia się. Językowe działania komunikacyjne konstytuuje zatem wspólny im wszystkim cel działania, cel porozumienia się ${ }^{17}$. Wypada się zapytać w tym miejscu, czy na wzór działań epistemicznych i teleologicznych, również językowe działania komunikacyjne możemy charakteryzować w oparciu o kategorię racjonalności, a jeżeli tak, to czym taka racjonalność różni się od dwóch pozostałych? J. Habermas w odpowiedzi na to pytanie rzecz ujmuje następująco: [...] Racjonalność komunikacyjna wyraża się $w$ jednoczacej sile mowy skierowanej na porozumienie się. Określa również mówiacym intersubiektywnie podzielony świat życia oraz obszar, w którym moga się oni odnosić do jednego i tego samego obiektywnego świata ${ }^{18}$.

Racjonalność komunikacyjna - naszym zdaniem - obejmuje swym zasięgiem jednocześnie aspekt transcendentalny językowego działania komunikacyjnego, jak i jego aspekt immanentny, wyrażony w swobodzie działania podmiotu co do zakresu spełnialność trzech relacji semantycznopragmatycznych.

Ewentualne roszczenia co do ważności (Gultigkeit) językowych działań komunikacyjnych muszą być zatem ustalone w swoiście pojmowane grze dialogowej-dyskursie. Na czym wobec tego swoistość owa dyskursu miałaby polegać?

Rozwiązania są dwa. W pierwszym z nich niektóre gry językowe - jak pamiętamy to z lektury Dociekań filozoficznych L. Wittgensteina ${ }^{19}$ - mogą mieć zasięg szerszy niż inne i nadawać się tym samym do objaśniania pozostałych. Powstałe w wyniku tych objaśnień nowe reguły językowe, możemy również stosować do dalszych czynności wyjaśniających. Nie możemy jednak tej procedury ciagnąć $w$ nieskończoność. Zważmy bowiem, że objaśnienie takie to tylko dalsze posunięcie w tej samej grze, posunięcie wedle tych samych reguł. Nie możemy wyjść poza zasięg reguł, ażeby im się przyjrzeć niejako z zewnątrz, w oderwaniu od naszego w nie zaangażowania. Dlatego też - zdaniem Wittgensteina - system reguł poszczególnych gier językowych nie poddaje się teoretycznej analizie, niemożliwa jest także ogólna teoria gier językowych. Końcowym punktem do którego semantyka zbudowana dla teorii gier językowych może dotrzeć, to dictum stwierdzające, że ostatecznym układem odniesienia jest wspólny wszystkim ludziom sposób działania, poprzez który interpretujemy dowolny język.

Pogląd ten jest podzielany przez bardzo wpływowych obecnie neopragmatystów amerykańskich W. Quine'a i D. Davidsona, w momencie kiedy formułują oni tezę o „nieuchwytności odniesienia

\footnotetext{
${ }^{16}$ Wittgenstein, L. Tractatus logico-philosophicus, Warszawa: Wydawnictwo Naukowe PWN, teza: 4.116.

17 Habermas J. 1999. Teoria działania komunikacyjnego. Warszawa: Wydawnictwo Naukowe PWN, ss. 506-508.

${ }^{18}$ Habermas, J. Pojęcie racjonalności..., s. 57.

${ }^{19}$ Por. Wittgenstein, L. Dociekania filozoficzne. Warszawa: Wydawnictwo Naukowe PWN, s. 82.
} 
przedmiotowego" (Quine) oraz tezę o wspomnianym wcześniej immanentnym pojęciu definicji prawdy (Davidson) ${ }^{20}$.

Propozycja J. Habermasa wydaje się przełamywać i wychodzić poza te relatywistyczne teorie semantycznie (tzn. rezygnujące z pytania o to jaka wiedza o świecie jest prawomocna). To, co dla Wittgensteina było punktem dojścia, dla J. Habermasa jest początkiem drogi do wyjaśnienia zawiłych problemów fenomenu komunikacji międzyludzkiej. Uniwersalnie i granicznie rozumiane przez Wittgensteina działania językowe, w teorii działań językowych prezentowane są z perspektywy epistemologicznej. Interesujące sa dla J. Habermasa tego typu działania językowe, które mają charakter aprioryczno-transcendentalny, czyli warunkujący wszelkie inne działania. Transcendentalność takich działań zasadza się na prawomocności norm wszelkiego dyskursu argumentacyjnego ${ }^{21}$. Kantowska, transcendentalna relacja między podmiotem poznającym a przedmiotem poznawanym zostaje zastapiona przez znaną nam już strukturę porozumienie się z kimś, co do czegoś. Jest to relacja podmiot -przedmiot - podmiot komunikacji. Stanowi ona podstawowy (wyjściowy) poziom prawomocności norm dyskursu argumentacyjnego. Uprawomocnienie dyskursu na tym podstawowym poziomie realizuje się zatem - używając retoryki K. O. Apela - w ramach relacji „hermeneutycznego myślenia”22 . Co ważne naszym zdaniem - takie ujęcie sprawy implikuje konsekwencje z której wnosimy, że uprawomocnienie transcendentalne w ramach hermeneutycznego rozumienia, swoją etykę dyskursu argumentacyjnego odnosi zarówno do dyskursu przyrodoznawczego, jak i do dyskursu humanistycznego, a dalej (na poziomie teorii nauki) do nauk przyrodniczych i nauk humanistycznych. Wymieńmy te normy, które dalej nazywać będziemy roszczeniami co do ważności działań:

- roszczenia do prawdy;

- roszczenia do prawdomówności lub też szczerości;

- roszczenia do słuszności warunkowane moralnie i normatywnie.

Transcendentalne wyprowadzenie roszczeń co do ważności działań - cytując J. Kmitę - polega na wykazaniu, iż „[...] nie można przeczyć im bądź kwestionować je argumentacyjnie np. na sposób sceptyków - ponieważ jakakolwiek wchodząca tu $w$ grę argumentacja musiałaby faktycznie zakładać, przynajmniej implicite, roszczenia, które chciataby negować. [...] Stąd [...] transcendentalno-pragmatyczna argumentacja nie polega tzw. 《detranscendentalizacji〉> (Rorty), o której powiada się, że zamknęta historię argumentacji transcendentalnych $w$ wyniku holistycznych zarzutów Quine'a czy odpowiednio - Davidsona"23.

Swoistość więc gry językowej - za J. Habermasem nazywanej dyskursem - polega na tym, że każdy kto w taka grę wchodzi jako uczestnik, bierze na siebie obowiązek spełnienia roszczeń co do ważności czynionych przez siebie działań językowych.

\footnotetext{
${ }^{20}$ Zob. Quine, W. V. 1997. Na tropach prawdy. Warszawa: Wydawnictwo Spacja, ss. $65-93$ lub Quine, W.V. 1993. Trzy niezdeterminowania. [W:] Stanosz, B. (red.) Filozofia jezyka. Warszawa: Wydawnictwo Spacja, ss. 121-140.

${ }_{21}$ Idea norm transcendentalnych dyskursu wydaje się być kontynuacja poglądów J. Habermasa z wcześniejszych okresów jego twórczości. Kluczowym pojęciem dla wyjaśnienia normatywnego charakteru wszelkiego dyskursu komunikacyjnego było pojęcie sytuacji idealnej rozmowy. Antycypacja idealnej rozmowy dokonuje się podczas każdej próby porozumienia się. Jest to taka sytuacja, w której proces komunikacji nie jest zakłócony ani przez warunki zewnętrzne ani przez przypadkowe okoliczności. Jest to rodzaj dyskursu, w którym liczą się wyłącznie lepsze argumenty. Realizacja idealnej rozmowy przebiega w ramach językowego medium. Ale, język to także zawsze pewne formy życia, odzwierciedlające idea ładu społecznego, w których komunikacja między ludźmi przybiera formę powszechnego, wolnego od przymusu i stosunków panowania dialogu. Zob. Habermas, J., Luhmann, N. 1971. Theorie der Gesellschaft oder Sozialtechnologie - Was leistet die Systemforschung? Frankfurt a. M.

${ }^{22}$ Ów fenomen, że ludzie mogą się wzajemnie rozumieć, rozmawiać ze sobą i argumentować, zakłada, że posiadają oni wspólne przedrozumienie (w sensie hermeneutyki H. G. Gadamera) bądź uznają wspólne reguły gry jezykowej (w sensie L. Wittgensteina). Por. Apel, K.O. 1971. Szientistik, Hermeneutik und Ideologiekritik. [W:] Hermeneutik und Ideologiekritik, Frunkfurt a. M.

${ }^{23}$ Cytat ten pochodzący od K.O. Apela podaję za: Kmita, J. 1995. Jak stowa tacza się ze światem. Poznań: Wydawnistwo Naukowe IF UAM, s. 24.
} 
Racjonalnymi - wobec powyższego - są wszystkie takie działania językowe, za treść których podmiot działający jest w stanie udzielić wiarygodnej gwarancji, a mianowicie takiej, że wnoszone roszczenia co do ważności działania będą mogły być ustalone w dyskursie. Istnieje zatem nierozerwalny związek między racjonalnością działania językowego, a jego potencjalnym usprawiedliwieniem - artykułowanym i sprawdzanym w dyskursie.

Obecnie pragniemy wskazać na dwie trudności natury metodologicznej i jedną natury ontologicznej, które dostrzegamy w teorii działań komunikacyjnych.

J. Habermas skłonny jest uważać, że zarówno działanie językowe epistemiczne jak i teleologiczne w większości sytuacji używane są w sposób niekomunikacyjny, tzn. nie są skierowane na porozumienie $\operatorname{się}^{24}$. Stanowisko to argumentuje przykładem użycia tzw. zwykłych twierdzeń (konstatacja: Miedź przewodzi prąd) lub działań w których podmiot powiadamiania o czymś samego siebie (Jutro wyjadę). Jak wiadomo, J. Habermas przyjął, że każde działanie realizowane w ramach medium językowego - zwane dalej przez nas działaniem językowym - jest lub też nie jest racjonalne. Działanie racjonalnym nie jest, jeżeli podmiot działania nie potrafi argumentować na rzecz jego ważności. Kategoria racjonalności odniesiona jest do wszystkich trzech typów działań językowych: epistemicznych, teleologicznych, komunikacyjnych. Racjonalność odniesiona do każdego z tych działań konstytuuje się $\mathrm{w}$ ramach możliwości argumentacji na rzecz ważności działań daną wypowiedzią wnoszonych.

Idąc konsekwentnie za myślą Habermasa stwierdzamy, że argumentacja ma swoje uprawomocnienie $\mathrm{w}$ transcendentalnych normach dyskursu. Zaś wszelka struktura dyskursu nie opiera się na relacji podmiot - przedmiot (semantyczne pytanie o to jak słowa łączą się ze światem) lecz na relacji podmiot - przedmiot - podmiot komunikacji. Wobec powyższego struktura porozumienia się jest tym elementem, który wspólny jest wszystkim działaniom językowym w stosunku do których jesteśmy skłonni pytać o racjonalność. Działania epistemiczne i teleologiczne są możliwe jako racjonalne, na tyle na ile skorelowane są z komunikacyjną strukturą porozumienia się. Jeśli w ogóle miałyby istnieć językowe działania niekomunikacyjne, to ich realizacja winna przebiegać poza strukturą porozumienia się. Tym samym działania takie pozbawione są pytań o ich ważność i racjonalność, tracąc w konsekwencji status działania jako takiego. Drugi $\mathrm{z}$ powodów $\mathrm{z}$ uwagi na który nie jesteśmy skłoni akceptować stanowiska J. Habermasa w sprawie niekomunikacyjnych działań językowych, motywuje przekonanie o tym, że argumentacja wewnętrzna jest tak samo skierowana na porozumienie się z kimś, co do czegoś, jak i argumentacja zewnętrzna. W dialogu wewnętrznym przyjmujemy bowiem rolę drugiej osoby (ty), co jak się wydaje, ma szczególne znaczenie dla wszelkich procesów twórczych i rzutuje na nasz sposób poznania świata. Uczymy się na negatywnych skutkach tylko dlatego, że potrafimy „in mante" wyciagać wnioski w ramach naszego dyskursu wewnętrznego. Przedstawione pewne komplikacje $\mathrm{z}$ rozumieniem komunikacyjnego $\mathrm{i}$ niekomunikacyjnego użycia wypowiedzi językowych, wydają się mieć swoje korzenie w tym, co J. Hintikka nazywa błędem powiązania trybu z grą językową 25 . Jego zdaniem wielu filozofów języka XX wieku dało się uwieść atrakcyjnej koncepcji Wittgensteina i Carnapa dotyczącej możliwości oddzielenia funkcji opisowej zdań od ich roli spełnianej w grach językowych. W zgodzie z tym poglądem tzw. rdzenie zdaniowe (frastyczne składniki zdań) są zrozumiałe dla użytkowników danego języka niezależnie od rodzaju gier w jakich występuja i dlatego mogą występować w grach różnego typu. Gry językowe natomiast nadają się do definiowania znaczenia w kategoriach użycia, ale nie rdzeni zdaniowych tylko elementów modalnych (neustycznych), które to elementy wraz ze rdzeniami zdaniowymi pozwalają na formułowanie zdań różnych typów (stwierdzeń, pytań, rozkazów, etc.) ${ }^{26}$.

\footnotetext{
${ }^{24}$ J. Habermas, Pojęcie racjonalności ..., s. 61.

${ }^{25}$ Por. Hintikka, J. 1992. Gry jezykowe. [W:] Eseje logiczno-filozoficzne. Warszawa: Wydawnictwo Naukowe PWN, ss. 447-486.

${ }^{26}$ Terminy „frastyczny” i „,neustyczny” pochodzą od Richarda Hare'a. Frastyczny - znaczy wskazujący, tj. wspólny dla zdań w trybie oznajmującym i rozkazującym; nuestyczny - potakujący, tj. właściwy dla trybu oznajmującego. Por. Hare, R. 1952. The Language of Morals. Oxford: Clarendon Press.
} 
Stąd też pomysł o wytyczeniu linii demarkacyjnej między opisowymi (epistemicznymi) i modalnymi (komunikacyjnymi) elementami języka Pomijając cały szereg niewątpliwie ważnych, ale i trudnych problemów z tym zagadnieniem związanych, podzielamy pogląd J. Hintikki, który dostrzega jednak możliwość powiązania języka z rzeczywistością i to wyłącznie dzięki grom językowym (działaniom językowym). Ale co ważne, gry językowe są już niezbędne do rozumienia wypowiedzi językowych na poziomie zdań oznajmujących, ponieważ wymagają one nie mniej powiązań świat - język, niż zdania jakiegokolwiek innego typu. Nie ma wypowiedzi językowych bez pierwiastka modalnego, tak jak nie ma wypowiedzi językowych bez aspektu pragmatycznego.

Na zarzut ontologiczny naraził się Habermas z chwila, gdy dla celów eksplikacyjnych własnej teorii działań komunikacyjnych zdecydował się zaadoptować teorię aktów mowy J. Searle'a. Błąd, który nazwiemy naturalistycznym polega na traktowaniu całkowicie teoretycznych bytów do jakich zaliczyć niewątpliwie należy akt mowy - w sposób naturalistyczny, czyli taki, w którym przedmiot badania traktuje się na wzór rzeczy, zjawiska czy sytuacji. Można odwołać się w tym miejscu do myśli G. Fregego i powiedzieć, że nieporozumienie to jest wynikiem pomieszania dwóch różnych stosunków: semantycznego stosunku oznaczenia przedmiotu przez nazwę i ontologicznego stosunku podpadania przedmiotu pod pojęcie. Akt mowy postrzegany jako byt teoretyczny służy do oznaczania określonych zjawisk, pojawiających się przy okazji komunikowania się jednostek ludzkich, a jako taki sam w sobie takim zjawiskiem nie jest.

Takie pomylenie stosunku semantycznego $\mathrm{z}$ ontologicznym prowadziło i prowadzi często do wielu różnych nieporozumień, które w obrębie pragmatyki kontrastywnej zaowocowało sporem dotyczącym statusu kategorii ekwiwalencji pragmatycznej ${ }^{27}$. Pojęcie ekwiwalencji pragmatycznej według W. Oleksego winno być definiowane następująco:

Wyrażenie językowe X1L1 jest ekwiwalentne pragmatycznie do wyrażenie językowego X2L2, jeżeli zarówno X1 jak $i$ X2 moga być użyte do tego samego aktu mowy w L1 i L2, gdzie: X1L1 oznacza wyrażenie w jednym języku; X2L2 oznacza wyrażenie $w$ drugim języku.

Tak sformułowana ekwiwalencja pragmatyczna zakłada pewien poziom, na którym poszczególne języki naturalne nie różniłyby się między sobą. Jest to mianowicie poziom identyfikacji aktów mowy. Problem i polemiki pojawiają się, gdy pytamy o procedurę na podstawie której taka identyfikacja aktów mowy ma nastapić. Wyjściem najprostszym i jednocześnie odpierającym wszelkie krytyki, jest przyjęcie założenia, że akty mowy we wszystkich językach mają charakter uniwersalny. Trudno mówić jednak o uniwersalizmie, gdy jak wykazują na to liczne analizy językoznawcze, ów charakter aktów mowy jest w istotny sposób determinowany społecznie i kulturowo. Na potwierdzenie tej tezy odwołamy się do przykładu przedstawionego przez antropologa kultury E. Leacha ${ }^{28}$. Wskazuje on, że w konwencji zachowań kultury anglosaskiej płacz znaczy smutek, śmiech znaczy radość, pocałunek znaczy miłość. Jednak te kulturowo warunkowane skojarzenia nie są ludzkimi uniwersaliami. Niekiedy symboliczno znakowe znaczenie jakiegoś działania może zupełnie odbiegać od reakcji sygnałowej, do której nawiązuje. Przykładowo płacz stanowi bardzo często część odpowiedniego zachowania żałobników na pogrzebie. Bywa jednak również, że oficjalni żałobnicy niekoniecznie są tymi, od których można oczekiwać, iż poruszeni są emocjonalnie. W wielu przypadkach ci co płaczą są po prostu wynajętymi płaczkami w ogóle nie spokrewnionymi ze zmarłym. Co więcej niekiedy płacz i śmiech mogą tworzyć część jednorodnego kontekstu; na chińskim weselu od krewnych panny młodej oczekuje się okazywania poprzez płacz straty, którą ponoszą jej rodzice, natomiast krewni pana młodego okazują swoją radość za pomocą śmiechu.

Trudność nie leży więc w sposobie identyfikacji poszczególnych aktów kulturowych lub aktów mowy (jest to warunkowane wyborem dyscypliny i metody opisu), lecz trudność leży w tym,

\footnotetext{
${ }^{27}$ Oleksy, W. 1984. Toward pragmatic contrastive analysis. [W:] J. Fisiak (red.) Constrastive linguistics: prospects and problems. The Hague: Mouton, ss. 349-365.

${ }^{28}$ Zob. Leach, E. 1989. Kultura i komunikowanie. Logika powiazań symbolicznych. Wprowadzenie do analizy strukturalnej w antropologii społecznej. [W:] J. Kmita, J. Topolski (red.) Rytuat i narracja. Warszawa PWN, ss. 16-98.
} 
co rzeczywiście badacze lingwiści chcą identyfikować: zjawiska same czy ich teoretyczne reprezentacje.

Badacze lingwiści pragnąc identyfikować podstawowe czynności komunikacyjne w rzeczywistości często uwagę swoją skupiają na sztucznych konstrukcjach, które nazywane są aktami mowy. Uniwersalnymi jednak mogą być tylko podstawowe działania komunikacyjne obecne we wszystkich kulturach i językach naturalnych. Status ten nie może przysługiwać środkom - w szczególności językowym - za pomocą których działania takie są realizowane. Nie wolno mylić nam czynności ze środkami, za pomocą których czynność ta jest realizowana. Akty mowy są środkami pragmatycznymi, za pośrednictwem których podmioty komunikacji realizują prymarne działania u podstaw danej komunikacji stojące. Akt mowy - jak się wydaje - jedynie wskazuje na czynność aktualnie zachodzącą w ramach wydarzenia komunikacyjnego. Aby zatem uniknąć komplikacji podobnych do tych, które towarzyszą pojęciu ekwiwalencji pragmatycznej, przy porównywaniu języków $\mathrm{w}$ ich aspekcie pragmatycznym $\mathrm{z}$ pewnością nie powinno iść o odpowiedniość poszczególnych rodzajów aktów mowy. Odpowiedniość tej winno szukać się na podstawowym poziomie działań komunikacyjnych, a nie na poziomie ich teoretycznego reprezentanta.

W podsumowaniu pragniemy zauważyć, iż całość rozważań zawartych w Teorii działań komunikacyjnych opiera się na metodologicznym założeniu, że to co w badaniach lingwistycznych zwykło nazywać się badaniem znaczeń wyrażeń języka, winno uwzględniać dwa poziomy organizacji procedur badawczych.

Pierwszy poziom obejmować winien wiedze tzw. deklaratywną, zawierająca stwierdzenia o faktach lub przekonaniach, wiedzę o organizacji wydarzeń i sytuacji w świecie rzeczywistym. Poziom drugi - nazywamy poziomem wymiany wiedzy - wymaga wiedzy proceduralnej, czyli takiej, w której fakty lub przekonania ujęte są w specjalnych formach typów użycia i rodzaju operacji językowych. Znaczenie wyrażeń języka jest jedynie specjalnym przypadkiem nabycia, zmagazynowania i zastosowania posiadanej przez nas wiedzy do wszelkiego rodzaju możliwych działań w świecie społecznym. Za takim rozumieniem pojęcia znaczenia przemawia fakt, że użycie wyrażeń języka wydaje się być procesem wysoce zróżnicowanym, ale jednocześnie względnie dobrze regulowanym umową społeczną. Badania lingwistyczne prowadzone w zgodzie z tym założeniem nazywane są semantyką proceduralną ${ }^{29}$.

Program budowy pragmatyki formalnej realizowany $\mathrm{w}$ obrębie semantyki proceduralnej ma szansę powodzenia o tyle, o ile uda się podać dla funkcji ekspresywnych i deklaratywnych języka listę uzasadnień analogicznych do tych, jakie semantyka prawdziwościowa podaje dla opisowej funkcji języka. Jednocześnie pojęcie racjonalności musi mieć na tyle ogólny charakter, by wychodziło poza prawdziwościową ważność zdań w sensie logicznym.

\section{Bibliografia}

Ajdukiewicz, K. 1985. Dyrektywy znaczeniowe. [W:] K. Ajdukiewicz (red.) Język i Poznanie, Warszawa: Państwowe Wydawnictwo Naukowe.

Ajdukiewicz, K. 1985. Metodologiczne typy nauk. [W:] K. Ajdukiewicz (red.) Język i Poznanie, Warszawa: Państwowe Wydawnictwo Naukowe, 286-313.

Ajdukiewicz, K. 1935. O spójności syntaktycznej. [W:] K. Ajdukiewicz (red.) Język i Poznanie, Warszawa: Państwowe Wydawnictwo Naukowe, 222-243.

Apel, K.O. 1971. Szientistik, Hermeneutik und Ideologiekritik. [W:] Hermeneutik und Ideologiekritik, Frunkfurt.

Austin, J.L. 1962. How to do Things with Words. Oxford: Clarendon Press.

Beangrande, de R. i Dressler, W.K. 1980. Wstęp do lingwistyki tekstu. Warszawa: Państwowe Wydawnictwo Naukowe, 121-122.

Buksiński, T. 1991. Szkice z filozofii dziatań. Poznań: Wydawnictwo Naukowe Instytutu Filozofii UAM.

\footnotetext{
${ }^{29}$ Por. Winograd, T. 1975. Frame representation and the declarative - procedural controversy, [W:] Bobrow i Collins (red.) Representation and Understanding: Studies in Cognitive Science, New York: Academic Press, ss. $185-210$.
} 
Davidson, D. 1992. Eseje o prawdzie, języku i umyśle. Warszawa: Wydawnictwo Naukowe PWN.

Fillmore, Ch.J. 1975. An alternative to checklist theories of meaning. Berkeley: Berkeley Lingustic Society, 123-131.

Frege, G. 1977. Pisma semantyczne. Warszawa: Państwowe Wydawnictwo Naukowe.

Gamut, 1991. Logic, Language and Meaning. Introduction to logic. Chicago/London: University of Chicago Press.

Gazdar, G. 1979. Pragmatics: implicature, presupposition and logical form. New York: Academic Press.

Grice, H. P. 1975. Logic and conversation. [W:] P. Cole, L. Morgan (red.) Syntax and Speech Act 3: Speech Acts, New York: Academic Press.

Habermas, J. 1997. Pojęcie racjonalności komunikacyjnej w świetle teorii aktów mowy. [W:] T. Buksiński (red.) Rozum i racjonalność, Poznań: Wydawnictwo Naukowe Instytutu Filozofii UAM.

Habermas, J. 1984. The theory of communicative action, Boston: Beacon Press.

Habermas, J. 1983. Teoria i praktyka. Warszawa: PWN.

Habermas, J., Luhmann, N. 1971. Theorie der Gesellschaft oder Sozialtechnologie - Was leistet die Systemforschung?, Frankfurt a. M.

Hare, R. 1952. The Language of Morals. Oxford: Clarendon Press.

Heyting, A. 1956. Intuitionism: An Introduction. Amsterdam: North Holland Publishing.

Hintikka, J. 1992. Eseje logiczno-filozoficzne. Warszawa: Wydawnictwo Naukowe PWN.

Hintikka, J. 1955. Form and content in quantification theory. Acta Philosophia Fennica, vol. VII, 7-55.

Kahneman, D., Thersky, J. 1978. The psychology of preferences. Scientific American, vol. 246, 160-173.

Kalisz, R. 1993. Pragmatyka językowa. Gdańsk: Wydawnictwo Uniwersytetu Gdańskiego.

Kant, I. 1957. Krytyka czystego rozumu. Warszawa: Wydawnictwo Naukowe PWN.

Kmita, J. 1995. Jak stowa taczq się ze światem. Poznań: Wydawnictwo Naukowe IF UAM.

Krasnodębski, S. Historia i krytyka. O teorii krytycznej Jurgena Habermasa. [W:] J. Habermas (red.) Teoria i praktyka, Państwowy Instytut Wydawniczy, 533-556.

Leach, E. 1989. Kultura i komunikowanie. Logika powiązań symbolicznych. Wprowadzenie do analizy strukturalnej w antropologii społecznej. [W:] J.Kmita, J. Topolski (red.) Rytuat i narracja. Warszawa: PWN, 16-98.

Leech, G. 1983. The Principles of Pragmatics. London: Longman.

Lenneberg, E.H. Biologiczne aspekty języka. [W:] B. Stanosz (red.) Język w świecie nauki. Warszawa: Spółdzielnia Wydawnicza "Czytelnik".

Levinson, S. 1983. Pragmatics. Cambridge: Cambridge University Press.

Loftus, G., Loftus, E. 1976. Human Memory: The Proccesing of Information. New York: Hillsdale.

Lorenzen, P., Lorenz, K. 1978. Dialogische logik. Darmstadt: Wissenschaftliche Buchgesellschaft.

Lyons, J. 1984. Semantyka. Warszawa: PWN.

Oleksy, W. 1984. Toward pragmatic contrastive analysis. [W:] J. Fisiak (red.) Constrastive linguistics: prospects and problems. The Hague: Mouton, 349-365.

Ouine, W. 1977. Filozofia logiki. Warszawa: PWN.

Quine, W.V. 1997. Na tropach prawdy. Warszawa : Wydawnictwo Spacja.

Quine, W.V. 1993. Trzy niezdeterminowania. [W:] B. Stanosz (red.) Filozofia języka. Warszawa: Wydawnictwo Spacja, 121-140.

Quine, W.V. 1960. Word and Object. Massachusetts: Massachusetts Institute of Technology Press.

Putnam, H. 1998. Wiele twarzy realizmu i inne eseje. Warszawa: Wydawnictwo Naukowe PWN.

Saussure, F. de. 1961. Kurs językoznawstwa ogólnego. Warszawa: PWN.

Schmidt, S. 1978. Some problems of communicative text theories. [W:] W. Dressler (red.) Current Trends in Text Linguistics. Berlin: Institut fur Sprachwissenschaft, 47-60.

Schutz, A. 1984. Potoczna i naukowa interpretacja ludzkiego działania. [W:] E. Mokrzycki (red.) Kryzys i schizma. Warszawa: Państwowe Wydawnictwo Naukowe.

Schutz, A. 1972. The Phenomenology of the social World, London.

Searle, J. 1987. Czynności mowy. Warszawa: Instytut Wydawniczy Pax.

Searle, J. 1979. Expression meaning. Cambridge: Cambridge University Press.

Searle, J. 1969. Speech acts. Cambridge: Cambridge University Press.

Searle, J., Vanderveken, D. 1985. Fundations of illocutionary logic. Cambridge: Cambridge University Press. Sperber, D., Wilson, D. 1986. Relevance. London: Blackwell.

Stampe, D. 1975. Meaning and truth in the theory of speech acts. [W:] P. Cale, J.L. Morgan (red.) Syntax and Semantics 3: Speech acts. New York: Academic Press, 1-38.

Wierzbicka, A. 1973. Akty mowy. [W:] R. Mayenowa (red.) Semiotyka i struktura tekstu, Wrocław: Ossolineum, 201-221.

Wierzbicka, A. 1969 Dociekania semantyczne. Wrocław: Ossolineum. 
Wierzbicka, A. 1980. Lingua mentalis. Sydney: Academic Press.

Winograd, T. 1975. Frame representation and the declarative - procedural controversy, [W:] Bobrow, Collins (red.) Representation and Understanding: Studies in Cognitive Science, New York: Academic Press, 185-210.

Wittgenstein, L. Dociekania filozoficzne. Warszawa: Wydawnictwo Naukowe PWN.

Wittgenstein, L. 1970. Tractatus Logico-Philosophicus. Warszawa: Państwowe Wydawnictwo Naukowe.

Wright von, H.G. 1951. An Essay in Modal Logic. Amsterdam: North-Holland Publishing.

Wright von, H.G. 1991. Explanation and Understanding. London: Routledge and Kegan Paul, 83-132. 